\title{
Possible impacts of climate change on wetlands and its biota in the Brazilian Amazon
}

\author{
Barros, DF ${ }^{a *}$ and Albernaz, ALM. ${ }^{a}$ \\ ${ }^{a}$ Coordenação de Ciências da Terra e Ecologia, Museu Paraense Emílio Goeldi, Av. Perimetral, 1901, \\ CEP 66077-830, Belém, PA, Brazil \\ *e-mail: dbarros@museu-goeldi.br
}

Received: March 19, 2013 - Accepted: August 7, 2013

(With 2 figures)

\begin{abstract}
Wetlands cover approximately $6 \%$ of the Earth's surface. They are frequently found at the interface between terrestrial and aquatic ecosystems and are strongly dependent on the water cycle. For this reason, wetlands are extremely vulnerable to the effects of climate change. Mangroves and floodplain ecosystems are some of the most important environments for the Amazonian population, as a source of proteins and income, and are thus the types of wetlands chosen for this review. Some of the main consequences that can be predicted from climate change for wetlands are modifications in hydrological regimes, which can cause intense droughts or inundations. A possible reduction in rainfall can cause a decrease of the areas of mangroves and floodplains, with a consequent decline in their species numbers. Conversely, an increase in rainfall would probably cause the substitution of plant species, which would not be able to survive under new conditions for a long period. An elevation in water temperature on the floodplains would cause an increase in frequency and duration of hypoxic or anoxic episodes, which might further lead to a reduction in growth rates or the reproductive success of many species. In mangroves, an increase in water temperature would influence the sea level, causing losses of these environments through coastal erosion processes. Therefore, climate change will likely cause the loss of, or reduction in, Amazonian wetlands and will challenge the adaptability of species, composition and distribution, which will probably have consequences for the human population that depend on them.
\end{abstract}

Keywords: global warming, wetlands, mangrove, floodplains, Amazonia.

\section{Possíveis impactos das mudanças climáticas em áreas úmidas e sua biota na Amazônia brasileira}

\begin{abstract}
Resumo
As áreas úmidas cobrem aproximadamente $6 \%$ da superfície da terra e são frequentemente encontradas na interface entre ecossistemas terrestres e aquáticos e fortemente dependentes do ciclo da água. Por esta razão são extremamente vulneráveis aos efeitos das alterações do clima. Os ecossistemas de manguezais e várzeas são muito importantes para os seres humanos da Amazônia, porque são de onde eles extraem algumas das principais fontes de proteínas e renda, e, por isso, foram os dois tipos de áreas úmidas escolhidos para esse estudo. Entre as principais consequências das mudanças climáticas previstas para esses ambientes estão as alterações nos regimes hidrológicos, que podem causar grandes secas ou inundações. A possível redução das chuvas pode causar a diminuição das áreas de mangue e várzea, provocando um rápido declínio de suas espécies. Por outro lado, o aumento das chuvas teria como provável consequência a substituição de espécies de plantas, que não seriam capazes de sobreviver sob as novas condições por um longo período de tempo. As principais consequências do aumento da temperatura da água entre as áreas úmidas seria que nas várzeas este parâmetro aumentaria a frequência ou duração dos episódios hipóxicos e/ou anóxicos, podendo causar a redução da taxa de crescimento e prejudicando o sucesso reprodutivo de muitas espécies, enquanto nos manguezais esta mudança influenciaria no nível do mar, provocando a perda desses ambientes pelo processo de erosão costeira. Portanto, tais mudanças poderão levar à perda e/ou redução das áreas úmidas da Amazônia, refletindo na capacidade de adaptação, composição e distribuição de suas espécies, consequentemente afetando as populações humanas que deles dependem.
\end{abstract}

Palavras-chave: aquecimento global, áreas úmidas, manguezais, várzeas, Amazônia. 


\section{Introduction}

Climate change refers to any change in climate conditions for any period of time, resulting either from natural causes, or by human action. Recently, climate change has been directly linked to the intensification of emissions of greenhouse gases on the terrestrial atmosphere (IPCC, 2007a). Greenhouse gases that are naturally found in the atmosphere are carbon dioxide $\left(\mathrm{CO}_{2}\right)$, ozone $\left(\mathrm{O}_{3}\right)$, methane $\left(\mathrm{CH}_{4}\right)$, nitrous oxide $\left(\mathrm{N}_{2} \mathrm{O}\right)$ and water vapour $\left(\mathrm{H}_{2} \mathrm{O}\right)$. The presence of these gases regulates the temperature of the Earth surface. However, since the industrial revolution, there is evidence that human activities, especially the burning of fossil fuels (coal, oil and natural gas), have caused an increase in the concentration of some greenhouse gases, especially $\mathrm{CO}_{2}$, which is considered to have the strongest effect on global warming.

The theme of climate change and global warming became part of the international agenda since the 1980s. In order to improve scientific knowledge on the issue, the World Meteorology Organization (WMO) and the United Nations Program for the Environment (UNPE), created, the Intergovernmental Panel on Climate Change (IPCC) in 1988, composed of renowned world scientists. As a result of meetings and data analysis, the IPCC edited and distributed four extensive scientific reports (in 1990, 1996, 2001 and 2007). Since the first report in 1990, the IPCC has identified increasingly stronger evidence of climate change and human action as the main cause of the increase on emissions of greenhouse gases.

According the IPCC's fourth report (IPCC, 2007a, b), within this century, the Earth will become $1.8-4{ }^{\circ} \mathrm{C}$ warmer, which would cause an increase in sea levels of $18-59 \mathrm{~cm}$. Furthermore, the increase in the Earth's temperature has led to climate events becoming more extreme, such as the melting of the glaciers, cyclones and storms, more intense floods and droughts, rapid desiccation of soils and the extinction of some animal and plant species, among others. Such changes would cause significant modifications on biogeochemical processes, including carbon dynamics, the dynamics and structure of food chains, primary and secondary production, and the capacity of adaptation of the biodiversity, resulting in changes in the extent, distribution and quality of habitats available for animal and plant species (Wrona et al., 2006).

Climate changes will affect tropical regions mostly due to changes in temperature and rainfall patterns. Projections of the future climate for Brazil, derived from global models, compiled by the IPCC, generally indicate a temperature increase for the whole country. However, for rainfall amounts and distribution regimes, results are divergent (Marengo, 2007; Marengo et al., 2009a, b). For the Amazon, for example, some models indicate drastic reductions in precipitation, whereas others predict an increase.

Drastic reductions in rainfall occurred in the Brazilian Amazon in 2005, when the water level of some of the large rivers of the basin dropped by up to $6 \mathrm{~cm}$ per day, drying floodplain lakes and creating problems for riverine populations that depend on water courses for transportation and for obtaining water and food (Fearnside, 2006; Marengo, 2007; Marengo et al., 2010; Tomasella et al., 2010). In contrast, in 2009, the Amazon basin was affected by extraordinarily strong rainfalls, which raised the water level of its rivers to a magnitude and duration rarely observed in the region, again causing economic and social damage to the human populations residing there (Marengo et al., 2011a, 2012). Extreme climatic events such as these are worrying in the Amazon region not only because they reach riverine populations, but also because they cause a loss of biodiversity (for example, millions of fish died in the 2005 drought in the region).

It is known that El Niño and La Niña events over the equatorial Pacific and the meridional gradient of Sea Surface Temperature (SST) anomalies in the tropical Atlantic together modulate much of the inter-annual variability of climate over South America, and might generate climate anomalies leading to droughts and floods in the Amazon (Marengo, 2007, Marengo et al., 2010). However, the 2005 drought did not result from El Niño, reinforcing the hypothesis that extreme weather events are likely to occur with more frequency and intensity in the region and can be influenced by climate change related to the greenhouse effect (Cox et al., 2008).

The probable impacts of global warming are a potential threat to the world as a whole, and in Brazil, the Amazon is one of the regions predicted to suffer the most severe impact (Fearnside, 2008b, 2009; Marengo et al., 2011a, b). This region is home to a great diversity of ecosystems, including several types of wetlands, among which some of the more important are the floodplains and mangroves, which support high biodiversity and productivity (Gopal and Junk, 2000). The impacts of climate change on wetlands in the Amazon will mainly affect aquatic biota and involve not only the loss of biodiversity but also sources of protein and income for the majority of the local human populations.

Currently, we know that the Amazon region is extremely vulnerable to climate extremes (e.g. those that occurred in 2005 and 2009). However, few studies exist on the possible effects of climate change on the Amazonian environments, and most of the existing studies are directed at terrestrial environments and species (Malhi et al., 2009; Feeley et al., 2012). Due to the absence of specific studies on the effects of climate change on the aquatic biota and environments, and even to the uncertainties associated with climate predictions for the region, it is still not possible to accurately interpret how climate change will affect the ecosystems of the Amazon and its fauna. However, it is possible to infer the possible consequences on Amazonian ecosystems. Therefore, based on the assumption that temperatures in the Amazon region will increase and that the precipitation regime will change, we conducted a literature review to describe the possible effects of climate change in two of the most important humid environments in the Amazon; the mangroves and floodplains, and inferior how these modifications might affect the local biota in general and the ichthyofauna in particular. 


\section{Wetlands}

Wetlands cover about $6 \%$ of the land surface and are often found at the interface between terrestrial ecosystems, such as forests and grasslands, and water, such as rivers, lakes, estuaries, and oceans (Mitsch and Gosselink, 2007). There are many terms and definitions used to describe wetlands; however, an accurate definition was proposed by several countries at the Convention on Wetlands, held in Iran in 1971, which is known as the Ramsar Convention. This convention defined wetlands as "areas of marsh, fen, peatland or water, whether natural or artificial, permanent or temporary, with water that is static or flowing, fresh, brackish or salt, including areas of marine water, the depth of which at low tide does not exceed six meters" (Ramsar, 1971, p. 246-247).

There are many benefits that wetlands provide for human society, including carbon cycling and climate regulation, the supply of fresh water, maintenance of biodiversity, fish production and tourism (Cox and Campbell, 1997; Keddy et al., 2009). Currently, there is great interest in preserving, maintaining or rehabilitating these ecosystems around the world, due to the understanding of their importance and wildlife for planning overall strategies for climate change mitigation (Millennium Ecosystem Assessment, 2005).

The environments of tropical wetlands are considered highly vulnerable to climate change and might be affected in four different ways: by changes in the hydrological regime; changes in precipitation patterns; local changes in temperature/humidity and subsequently in patterns of evapotranspiration, and increases in the frequency of extreme climate events. Added to these, the coastal wetlands, such as mangroves, might also be influenced by the rising of sea levels (Mitsch et al., 2010).

Amazonian wetlands vary considerably regarding hydrology, soil, vegetation, species diversity of plants and animals, and primary and secondary production (Junk et al., 2011). In this region are several types of wetlands can be found (Prance, 1980; Junk et al., 2011), among which mangroves and floodplains (forests periodically flooded by white water rivers) are the most important as sources of food and income for human populations. Therefore, these two types of Amazonian wetlands were chosen for this study. Mangroves are characterized by a polymodal flood pulse of low amplitude and duration, resulting from the influence of the tide, while in the floodplains the flood pulse is monomodal, with larger amplitude and longer duration (Junk, 1997). The flood pulses and/or tidal movements affect the reproduction rate of plant and animal species, as well as extensive economic activities, which in general, are conditioned by water fluctuations, either daily (e.g. mangroves) and/or seasonally (e.g. floodplains) (Pires, 2011).

As a result of global warming, assuming that temperatures will increase and the precipitation regime will change (either increase or decrease), we sought to describe the possible effects of climate change on the mangroves and floodplains of the Amazon and its implications for its biota, separately for the following scenarios: with increased temperature, and either increased or reduced precipitation. Discussion will be limited to the most likely changes or to those more likely to cause changes in the structure or functioning of these environments.

\section{Possible Effects of Climate Change in Amazonian Mangroves}

Mangroves occur in tropical and subtropical latitudes between $25^{\circ} \mathrm{N}$ and $25^{\circ} \mathrm{S}$ (Nicholls et al., 2007) at the shores of oceans and estuaries, in the intertidal zone. They also occupy shallow flooded areas of deltas and lagoons (Cintrón-Molero and Schaeffer-Novelli, 1995). They consist of muddy sediments, colonized mainly by associations of Ryzophora ssp., Avicenia ssp., Laguncularia sp. e Spartina sp. (Souza Filho and El-Robrini, 1997). Few animal species exclusively inhabit mangrove forests (Lacerda and Kjerfve, 1999) and most of the fish species found at these sites are visitors (Barros et al., 2011), found in these environments depending on the season, tide, or life cycle stage (Lacerda et al., 1993).

About $90 \%$ of mangroves around the world occur in hot and humid regions, where precipitation exceeds evapotranspiration, as for those occurring on the northern coast of Brazil (Blasco, 1984). The mangroves of the northern Brazilian coast occur abundantly throughout the Amazon estuary along the coast of Amapá, Pará and Maranhão, where they occupy an area of $9,000 \mathrm{~km}^{2}$, which represents $70 \%$ of Brazil's mangroves and constitute one of the largest continuous areas of mangrove in the world (Menezes and Mehlig, 2009). The Amazonian coastal zone has peculiar meteorological and oceanographic characteristics, including a high annual rainfall (up to $3,300 \mathrm{~mm}$ ), high temperatures $\left(>20^{\circ} \mathrm{C}\right.$ ) with low annual thermal variation (up to $5^{\circ} \mathrm{C}$ ), a wide continental shelf $(\sim 330 \mathrm{~km})$, and a macrotidal regime, with maximum values of $8 \mathrm{~m}$ in Maranhão, $6 \mathrm{~m}$ in Pará and $12 \mathrm{~m}$ in Amapá (Pereira et al., 2009).

Worldwide, the area of mangroves has been reduced by approximately $20 \%$ between 1980 and 2005 . This trend was not observed in Brazil, where the reduction was only 5\% in the same period (Neves and Muehe, 2008), but recently, mangrove areas in Brazil are losing area to the uncontrolled urban expansion of the coastal zone. In northeastern Brazil, for example, mangroves are being destroyed for shrimp farming. In the Amazon, mangroves are also shrinking due to an increase of tourism activities and construction of roads (Menezes and Mehlig, 2009). This makes it is difficult to distinguish alterations caused by climate change from those caused by human activities.

Mangroves are of great ecological importance because they are place of breeding and act as nurseries for many species of fish and crustaceans, which find food in this environment as well as shelter and shade for their larvae and juveniles (Menezes and Mehlig, 2009). For fish, depending on the species and latitudinal distribution, the impact of climate change can be either positive and/ 
or negative, and can affect their physiology (growth, reproduction) and behavior (migration) (Brander et al., 2003). Consequently, climate effects can cause changes in the composition, abundance and spatial distribution of species (Wrona et al., 2006; IPCC, 2007b), depending upon the scenario that is going to succeed.

\subsection{The temperature increase scenario}

Mangroves tend to respond positively to the combined effect of rising $\mathrm{CO}_{2}$ levels and global temperature increase, which will raise the photosynthetic capacity and reduce evapotranspiration from plants, thus resulting in an increment in the productivity of some species (Field, 1995; Ellison, 2000; Lacerda et al., 2002). Furthermore, with the progressive increase in the regional average temperature of the air and/or sea, an expansion of the distribution areas of some mangrove species to higher latitudes, where the distribution is currently limited by temperature, might occur (Kjerfve and Macintosh, 1997), since the direction of ocean currents favor dispersal (Lacerda et al., 2002).

In Amazon mangrove ecosystems where the water temperature is already high, the distribution of fish and shellfish must quickly adjust to the increase in temperature caused by climate change (Kjerfve and Macintosh, 1997). However, Ficke et al. (2007) have suggested that a small increase in the temperature $\left(1^{\circ} \mathrm{C}\right.$ to $\left.2^{\circ} \mathrm{C}\right)$ can be sufficient to cause sub-lethal physiological effects in tropical fish (particularly in reproduction), especially when combined with possible hydrological changes.

Another expected effect related to the increase in global temperature of the planet is the rising of the sea level as a result of the ice melting of icecaps (Berchez et al., 2008). Rising sea level is among the main consequences of climate change and probably will negatively affect ecosystems and mangrove species. Due to their location between land and the sea, these will probably be among the first ecosystems to be affected by such changes. Mangrove characteristics depend on various climatic factors that influence the stability of the coast and the balance between erosion and sedimentation (Lacerda et al., 2010).

In principle, the increase in sea level would favor the expansion of mangroves to higher areas that were previously occupied by terrestrial or freshwater environments, which will be progressively invaded by salty water and favor the migration of mangroves. However, in many parts of the world, mangroves are prevented from migrating toward the mainland because of human occupation, which would probably result in a decrease in mangrove areas with the rising of the sea level (Kjerfve and Macintosh, 1997). Therefore, the effect of sea level rise for some mangrove areas will depend on local conditions such as the type of wetland, geomorphological characteristics and the type and intensity of human activity.

The specific impacts of marine transgressions on mangroves would result in increased flood risk, coastal erosion and saltwater intrusion (Lacerda et al., 2002). Regarding the effects on the Amazonian coastal region, Muehe and Neves (1995) suggest that progradation of tide into the low elevation rivers such as those in northern Brazil will reflect mangrove loss resulting from coastal erosion. According to Ellison (1994), the erosion of mangrove substrate is regarded as the greatest problem resulting from rising sea levels. Depending on the amount of sediment, alluvial lowlands such as those at Marajó Island at the mouth of the Amazon River might be flooded (Marengo and Soares, 2003). It is noteworthy that the mangroves of the coast of Pará and Maranhão were formed during the late Holocene, favored by the lowering of the sea level (Kjerfve et al., 2002; Ab'Sáber, 2004). A summary of the possible effects of climate change on the mangrove environment and its biota can be seen in Figure 1.

\subsection{The increased rainfall scenario}

According to Duke et al. (1998), coastal areas with high precipitation, high run-off of sediments, nutrients and organic matter, and high river input, such as the Amazon - which represents $16 \%$ of the freshwater discharged into

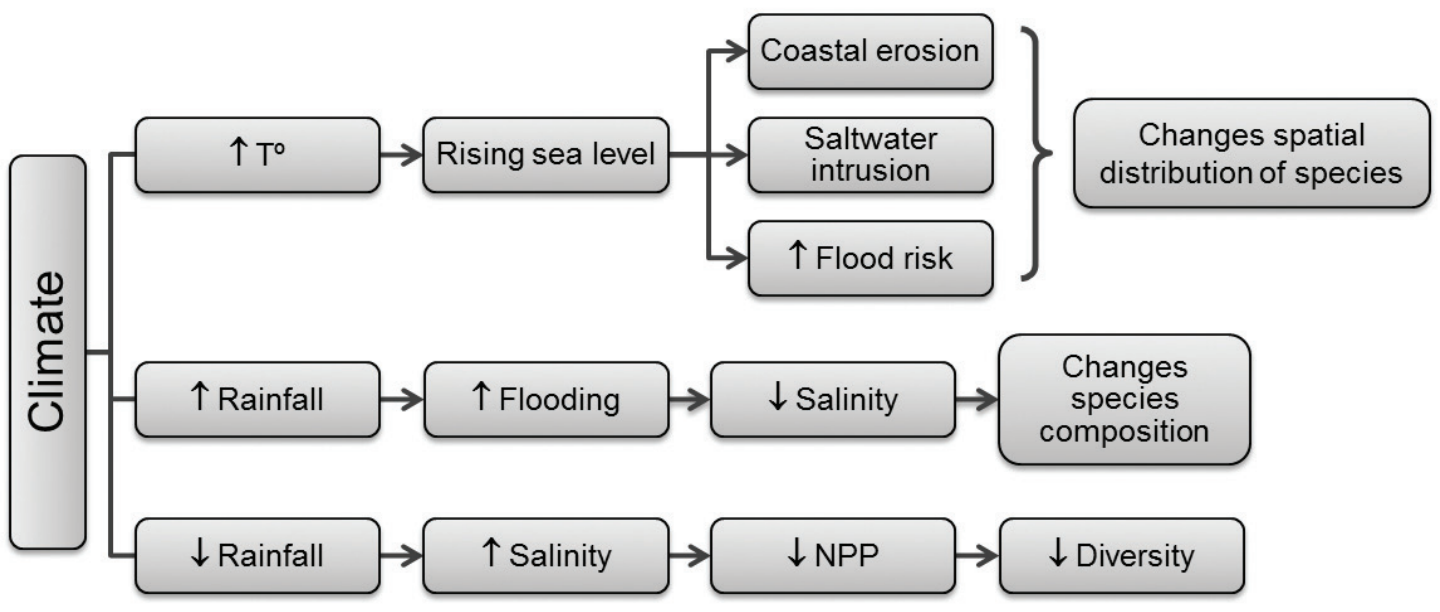

Figure 1. Graphic scheme of the possible impacts of climate change on the mangrove environment and its biota. 
the oceans (Pereira et al., 2009), tend to support higher and more diversified forest species. Rainfall and abundant river input carry muds and sands to tidal plain, forming a substrate for mangrove colonization, and also leach salts from the soil, making salinity levels constantly low and stable (Kjerfve et al., 2000). Apart from providing optimal conditions for the development of mangroves, this also favors the occurrence of freshwater species associated with this ecosystem, making it especially diverse (Kjerfve and Lacerda, 1993).

However, extreme climate events, such as long periods of flooding associated with the low salinity found in the Amazon coastal zone, might contribute to the degradation or loss of mangroves in the region. Mangroves of Maranhão, for example, might disappear altogether if the flow of freshwater dominates the tidal prism, causing the replacement of mangrove species by macrophytes (Lacerda et al., 2002). Many fish use the mangroves directly for at least some period of their life cycle, or might indirectly rely on resources derived from it (Giarrizzo and Krumme, 2009). The replacement of brackish water by freshwater in these environments will cause the elimination of a very important habitat for many species of fish, crustaceans and molluscs, and the probable loss of mangrove species (Mumby et al., 2004).

Therefore, as a consequence of the degradation or loss of mangroves, several species of larvae and juvenile fish will not be able to develop, thus resulting in adverse consequences to stocks and adult captures, profoundly affecting the population that depends on fishing for a living (Kjerfve and Macintosh, 1997; Gilman et al., 2007). Moreover, many species exploited by commercial fisheries are already overexploited. Without replenishing, fish stocks of these species possibly will become extinct, leading to economic, social and ecological consequences.

\subsection{The decreased rainfall scenario}

The decrease in rainfall and increased evaporation will increase soil salinity, reducing the primary production and diversity of the mangroves. It will also cause a noticeable reduction in mangrove area due to the conversion of the supra-tidal zone into hyper-saline plains (Field, 1995; Ellison, 2000; Gilman et al., 2008). In a short period of time, some species of freshwater aquatic biota will not be able to survive and reproduce under the new hydrological conditions and increased salinity (Nielsen and Brock, 2009). According to the same authors, the increased salinity will not only bring direct impacts on the biotic community, but also indirect effects, affecting the entire food web of aquatic biota due to the reduction in primary production. Associated with the loss of mangrove habitat, important for the reproduction of many species, fishery resources (local and regional) will be dramatically reduced.

\section{Possible Effects of Climate Change in Amazonian Floodplains}

The Amazonian floodplains are considered the most extensive flooded forests of Earth (Vieira, 2006), covering an area of approximately 200,000 km² (Junk, 1993, 1997), which corresponds to about $20 \%$ of the Amazon basin (Junk and Piedade, 2004). They are characterized by muddy water (also called white), rich in nutrients and sediments (Furch and Junk, 1997), and drain soils of Andean origin. The Solimões/Amazonas system occupies the largest portion of the Amazonian floodplains; its large water volume results from the sum of rainfall over the catchment and Andean annual thaw (Junk et al., 1989).

The floodplains function as places of shelter, feeding, breeding and as a nursery for a large number of species, including many commercially exploited fish (Junk, 1997). Junk and Piedade (2004) estimate that about half of the fish species of the Amazon occur in systems of large rivers associated with floodplains, whereas the other half has a very restricted distribution and occurs only in the headwaters associated with humid areas. The regional and local climate, along with characteristics of the drainage area (topography, vegetation, soils), regulate the water temperature and the hydrological regimes of freshwater environments (Mulholland et al., 1997; Poff and Zimmerman, 2010). Aquatic environments in the Amazon exhibit seasonal cycles, determined mainly by wind and rain, which are responsible for the oscillation of the flow and hence the fluctuation of the water level (Lowe-McConnell, 1999). The fluctuations of the water level of the Amazon floodplains have a regular period of high and low water (Barthem and Fabré, 2004). The annual pattern of variation in water level, called "flood pulse" (Junk, 1997), is the main factor responsible for the existence, productivity and interaction of the biota that live in the floodplains (Junk et al., 1989).

It is expected that these environments will be affected by changes in precipitation, temperature and evaporation, which would cause changes in the input of nutrients and debris, and the frequency and intensity of droughts and floods (Mulholland et al., 1997; Meyer et al., 1999; Lake et al., 2000; Erwin, 2009). Changes in the hydrological regime might also modify the physicochemical properties of the soil, directly impacting the wetland biota (Carpenter et al., 1992; Burkett and Kusler, 2000; Lake et al., 2000). Concerning floodplain environments, changes in flood pulse and the relationship between water and adjacent terrestrial systems can affect the biodiversity and the health of the system, with serious ecological and socio-economic consequences (Tundisi and Matsumura-Tundisi, 2008).

\subsection{The temperature increase scenario}

In recent decades, there is growing evidence of a significant acceleration of loss of glacier mass in the tropical Andes due to the rising temperature of the earth (Francou et al., 2000; Ramírez et al., 2001; Francou et al., 2003). According to Ramírez (2008), in the short term, this massive loss of glaciers will cause an increase in the flow of watercourses. However, with a decreasing ice surface, this initial increase of water flow will be followed by a deficit in the flow. Moreover, the loss of Andes ice will cause considerable changes in the volume of sediments carried into the Amazonian rivers (FBMC, 2008). It is 
noteworthy that the input of sediment from the Andes is mainly responsible for the enormous productivity of the floodplains, due to the high concentration of nutrients in suspension carried with the clays (Queiroz, 2005).

Water temperature influences the solubility of oxygen (Lowe-McConnell, 1999) and with a probable increase in water temperature together with a large biological oxygen demand (as occurs in floodplains), the concentration of oxygen will further reduce or even make this environment hypoxic or anoxic for longer periods (Ficke et al., 2007). Hypoxic and anoxic episodes can be devastating to many ecosystems and can cause mass mortality, extinction of benthic communities, decline in fishery production and biodiversity loss (Almeida-Val et al., 2007).

Floodplain environments are already highly hypoxic during certain periods of the year (Junk, 1997). However, some species have adapted to live in these conditions (Junk et al., 2007), especially with regard to breathing, both for aquatic organisms such as fish, as well as terrestrial ones, such as trees (Parolin et al., 2004). This makes it difficult to predict the effect of a prolonged deficit and/or lack of oxygen on the flora and fauna of the floodplains.

According to Ficke et al., 2007, the increase in the frequency or duration of hypoxic and or anoxic episodes might reduce growth rates and impair the reproductive success of fish species, thus jeopardizing the recovery of adults stocks. However, the situation might become even more limiting, because under anaerobic conditions, harmful gases such as hydrogen sulfide and methane can form, which could cause the death of many organisms, particularly fish (Esteves, 1998).

Increased water temperature might also affect fish, especially with respect to physiological adjustments of individual species (Ficke et al., 2007). Generalist species might temporarily face an increase in water temperature by searching for places with lower temperatures, such as the mouths of rivers or forest creeks (Zuanon, 2008), however specialists will presumably suffer population reduction due to changes in the thermal regime (Ficke et al., 2007). A summary of the possible effects of climate change on the floodplain environment and its biota can be seen in Figure 2 .

\subsection{The increased rainfall scenario}

The increase in the water level of the Amazon and Solimões Rivers establishes a connection of the main channel with floodplain lakes (Junk, 1997; Goulding, 1999). This connection is transient, influenced by changes in the hydrological cycle and is characterized by a strong unidirectional flow from rivers towards the lakes during seasonal flooding (Freitas and Garcez, 2004; Sousa and Freitas, 2008). One immediate effect of increased rainfall will be an increase in the velocity of water flow, accompanied by a large movement of sediments that might cause the displacement and death of many fish (Pujolar et al., 2011).

The Amazon floodplain contains large areas of forest that are flooded during the high water season, forming complex habitats, composed of submerged roots, leaves and stems, which provide refuge and food for both fish and aquatic invertebrates (Junk, 1997). Increased rainfall might lead to a sharp rise in water levels and consequently to a loss of protected areas for juvenile fish and other aquatic organisms, making them vulnerable to the movements of the stream and to the action of predators. The magnitude and duration of flooding is a major factor for the reproduction and survival of wetland species (Pitchford et al., 2012). If the increased rainfall leads to longer periods of flooding, it will possibly result in the death of flooded forest and the eventual replacement of aquatic plants (Poff et al., 2002). Moreover, many invertebrate species that migrate to the

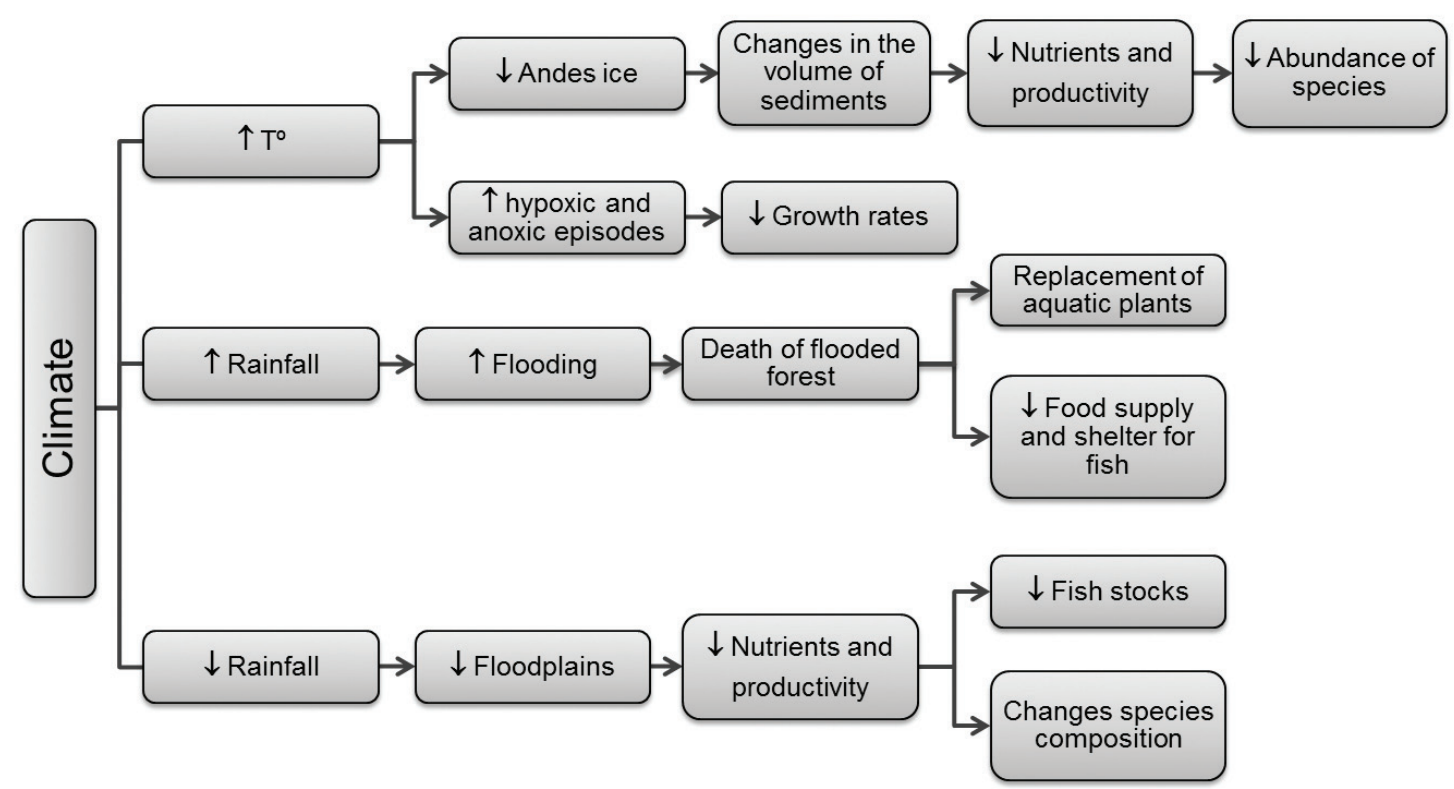

Figure 2. Graphic scheme of the possible impacts of climate change on the floodplains environment and its biota. 
trunk or the canopy, to survive during the aquatic phase, will also die (Junk and Piedade, 2004).

Many fish species depend on allochthonous material derived from flooded forests, such as leaves, fruits and insects, as well as the flooded forest depending on the fish fauna for seed dispersal (Lowe-McConnell, 1999). The elimination of the flooded forest might cause a decrease in food supply and shelter for fish and other aquatic organisms that depend on these sites, resulting in the reduction of fish stocks, which in turn, directly affects the lives of people who depend on fishing for a living (Ruffino, 2004).

\subsection{The reduced in rainfall scenario}

The reduction in rainfall could lead to longer periods of low water levels in rivers and prolonged drought in the Amazon floodplain (Marengo and Nobre, 2001). These conditions associated with increased evapotranspiration, might reduce the extent of flooded areas or convert them into drylands (Burkett and Kusler, 2000). The absence of an adequate period of flooding, in magnitude, duration and time, might cause a decline of many species which depend on flooding to complete their life cycle, and, in addition, might promote the establishment of invasive species (Poff, 2002; Döll and Zhang, 2010).

Intense droughts might rapidly decrease water availability in floodplain soils. The rapid drying of the soil will affect seed germination, seedling recruitment and photosynthetic activity, and thus decrease productivity and alter species composition (Parolin et al., 2010). Moreover, prolonged drought might also increase the risk of forest fires, thus causing losses of species at local and regional scales (Fearnside, 2008a; Malhi et al., 2009).

The reproductive success of most fish species is largely governed by the timing, duration and intensity of floods, since there is synchronization between the phases of the hydrological cycle and biological events such as gonadal maturation, migration, spawning and early development of larvae and fingerlings (Agostinho et al., 1993; LoweMcConnell, 1999). Low levels of flooding will not allow the connection of the main channel of the river to other floodplain areas, preventing the exchange of nutrients and organic matter and the access of larval and juvenile fish to suitable locations to complete their development. Moreover, populations of fishes that depend on lakes and permanent wetlands might be severely affected by the decline in rainfall, mainly due to mass mortality, if they become trapped in shallow and warm small lakes (Zuanon, 2008).

Initially, the negative effects of reduced rainfall might be masked by the ease of capturing stocks produced by previous floods. However, with the reduction of floodplains, the carrying capacity of the environment will probably decrease, causing an increase in natural mortality, reduced growth rates and reduction in fish stocks, resulting in impaired recruitment, which might severely affect fishing in the Amazon region in the subsequent years.

\section{Conclusion}

One of the main consequences of climate change in the Amazon region will be changes in hydrological patterns, which would occur in all considered scenarios. Either an increase or reduction in rainfall will impact Amazonian wetlands negatively, both for mangroves and floodplains. Longer periods of drought or floods might cause the loss of humid ecosystems in the Amazon and consequently cause changes in the composition and distribution of species of fauna and flora adapted to these environments, characterized by fluctuations in the fluvial-lacustrine and fluvial-marine regimes. As a result, the human populations that depend on these systems for subsistence will also be impacted, socially and economically. It is noteworthy that these impacts will be more drastic when combined with other anthropogenic changes on these environments. Therefore, reducing the anthropogenic impacts on wetlands would represent one of the first steps to minimize the negative impacts of climate change in these environments of great importance to the survival of many species and also for subsistence of human populations. Moreover, the current conservation of these areas is considered to be the best way to mitigate climate change impacts.

\section{Acknowledgements}

We thank the Ministério da Ciência e Tecnologia (MCT) and the Instituto Nacional de Pesquisas Espaciais (INPE) for their support through the Brazilian Research Network on Climate Change (Climate Network) and the Conselho Nacional de Desenvolvimento Científico e Tecnológico (CNPq) for the research grant for the first author (Proc. 383581/2011-7).

\section{References}

AB'SÁBER, AN., 2004. Amazônia: do discurso à práxis. São Paulo: Edusp. 319 p

AGOSTINHO, AA., VAZZOLER, AEA., GOMES, LC. and OKADA, EK., 1993. Estratificación espacial y comportamiento de Prochilodus scrofa en distintas fases del ciclo de vida, en la planície de inundación del alto río Paraná y embalse de Itaipu, Paraná, Brasil. Revue d'Hydrobiologie Tropicale, vol. 26, no. 1, p. 79-90

ALMEIDA-VAL, VMF., CHIPPARI-GOMES, AR., LOPES, NP., ARAÚJO, R., NOZAWA, SR., FERREIRA-NOZAWA, MS., PAULA-SILVA, MN. and VAL, AL., 2007. Biochemical responses to hypoxia: The case of amazon fishes. In Proceedings of the Ninth International Symposium on Fish Physiology, Toxicology, and Water Quality, 2006. Georgia. Georgia: EPA. p. 13.

BARROS, DF., TORRES, MF. and FRÉDOU, FL., 2011. Ictiofauna do estuário de São Caetano de Odivelas e Vigia (Pará, Estuário Amazônico). Biota Neotropica, vol. 11, no. 2, p. 367-373. http:// dx.doi.org/10.1590/S1676-06032011000200035.

BARTHEM, RB. and FABRÉ, NN., 2004. Biologia e diversidade dos recursos pesqueiros da Amazônia. In RUFFINO, ML. (Coord.). A pesca e os recursos pesqueiros na Amazônia brasileira. Manaus: Ibama/ProVárzea. p. 17-62. 
BERCHEZ, FA., O-FILHO, EC., AMÂNCIO, CE. and GHILARDI, NP., 2008. Possíveis impactos das mudanças climáticas globais nas comunidades de organismos marinhos bentônicos da costa brasileira. In BUCKERIDGE, MS. (Ed.). Biologia e mudanças climáticas no Brasil. São Carlos: RiMa Editora. p. 167-191.

BLASCO, F., 1984. Climatic factors and the biology of mangrove plants. In SNEDAKER, SC. and SNEDAKER, JG. (Eds.). The mangrove ecosystem: research methods. Paris: UNESCO. p. 18-35.

BRANDER, KM., BLOM, G., BORGES, MF., ERZINI, K., HENDERSON, G., MACKENZIE, BR., MENDES, H., RIBEIRO, J., SANTOS, AMP. and TORESEN, R., 2003. Changes in fish distribution in the eastern North Atlantic: Are we seeing a coherent response to changing temperature? ICES Marine Science Symposia, vol. 219 , p. 261-270.

BURKETT, V. and KUSLER, J., 2000. Climate change: potential impacts and interactions in wetlands of the United States. Journal of the American Water Resources Association, vol. 36, no. 2, p. 313-320. http://dx.doi.org/10.1111/j.1752-1688.2000.tb04270.x.

CARPENTER, SR., FISHER, SG., GRIMM, NB. and KITCHELL, JF., 1992. Global change and freshwater ecosystems. Annual Review of Ecology and Systematics, vol. 23, no. 1, p. 119-139. http://dx.doi.org/10.1146/annurev.es.23.110192.001003.

CINTRÓN-MOLERO, G. and SCHAEFFER-NOVELLI, Y., 1995. Ecology and Management of New Word Mangroves. In SEELIGER, U. (Ed.). Coastal Plant Communities of Latim América. San Diego: Academic Press. p. 233-258.

COX, KW. and CAMPBELL, L., 1997. Global Climate Change and Wetlands. Canada: Issues and Awareness. 26 p.

COX, PM., HARRIS, PP., HUNTINGFORD, C., BETTS, RA., COLLINS, M., JONES, CD., JUPP, TE., MARENGO, JA. and NOBRE, CA., 2008. Increasing risk of Amazonian drought due to decreasing aerosol pollution. Nature, vol. 453, no. 7192, p. 212-215. http://dx.doi.org/10.1038/nature06960. PMid:18464740

DÖLL, P. and ZHANG, J., 2010. Impact of climate change on freshwater ecosystems: a global-scale analysis of ecologically relevant river flow alterations. Hydrology and Earth System Sciences, vol. 14, no. 5, p. 783-799. http://dx.doi.org/10.5194/ hess-14-783-2010.

DUKE, NC., BALL, MC. and ELLISON, JC., 1998. Factors influencing biodiversity and distributional gradients in mangroves. Global Ecology and Biogeography Letters, vol. 7, p. 27-47. http:// dx.doi.org/10.2307/2997695.

ELLISON, J., 1994. Climate change and sea level rise impacts on mangrove ecosystems. In PERNETTA, JC., LEEMANS, R., ELDER, D. and HUMPHREY, S. (Eds.). The impact of climate change on ecosystems and species: marine and coastal ecosystems. A Marine Conservation and Development Report. Switzerland: IUCN. p. 11-30.

ELLISON, J., 2000. How South Pacific mangroves may respond to predicted climate change and sea level rise. In GILLESPIE, A. and BURNS, W. (Eds.). Climate Change in the South Pacific: Impacts and Responses in Australia, New Zealand, and Small Islands States. Netherlands: Kluwer Academic Publishers. p. 289-300. http://dx.doi.org/10.1007/0-306-47981-8_16.

ERWIN, KL., 2009. Wetlands and global climate change: the role of wetland restoration in a changing world. Wetlands Ecology and Management, vol. 17, no. 1, p. 71-84. http://dx.doi.org/10.1007/ s11273-008-9119-1.
ESTEVES, FA., 1998. Fundamentos de Limnologia. 2nd ed. Rio de Janeiro: Interciência. 602 p.

FEARNSIDE, PM., 2006. Desmatamento na Amazônia: dinâmica, impactos e controle. Acta Amazonica, vol. 36, no. 3, p. 395-400. http://dx.doi.org/10.1590/S0044-59672006000300018.

FEARNSIDE, PM., 2008a. Deforestation in Brazilian Amazonia and global warming. Annals of Arid Zone, vol. 47, no. 3-4, p. 1-20.

FEARNSIDE, PM., 2008b. Mudanças climáticas globais e a floresta amazônica. In BUCKERIDGE, MS. (Ed.). Biologia e Mudanças Climáticas Globais no Brasil. São Paulo: RiMa Editora. p. 131-150.

FEARNSIDE, PM., 2009. Global warming in Amazonia: Impacts and Mitigation. Acta Amazonica, vol. 39, no. 4, p. 1003-1011. http://dx.doi.org/10.1590/S0044-59672009000400030.

FEELEY, KJ., MALHI, Y., ZELAZOWSKI, P. and SILMAN, MR., 2012. The relative importance of deforestation, precipitation change, and temperature sensitivity in determining the future distributions and diversity of Amazonian plant species. Global Change Biology, vol. 18, no. 8, p. 2636-2647. http://dx.doi. org/10.1111/j.1365-2486.2012.02719.x.

FICKE, AD., MYRICK, CA. and HANSEN, LJ., 2007. Potential impacts of global climate change on freshwater fisheries. Reviews in Fish Biology and Fisheries, vol. 17, no. 4, p. 581-613. http:// dx.doi.org/10.1007/s11160-007-9059-5.

FIELD, C., 1995. Impacts of expected climate change on mangroves. Hydrobiologia, vol. 295, no. 1-3, p. 75-81. http:// dx.doi.org/10.1007/BF00029113.

FÓRUM BRASILEIRO DE MUDANÇAS CLIMÁTICAS FBMC, 2008. Vulnerabilidade climática. Rio de Janeiro: IVIG - COPPE/UFRJ. 58 p.

FRANCOU, B., RAMÍREZ, E., CÁCERES, B. and MENDOZA, J., 2000. Glacier evolution in the tropical Andes during the last decades of the 20th century: Chacaltaya, Bolivia, and Antizana, Ecuador. AMBIO: A Journal of the Human Environment, vol. 29 , no. 7, p. 416-422.

FRANCOU, B., VUILLE, M., WAGNON, P., MENDOZA, J. and SICART, J-E., 2003. Tropical climate change recorded by a glacier in the central Andes during the last decades of the twentieth century: Chacaltaya, Bolivia, $16^{\circ} \mathrm{S}$. Journal of Geophysical Research, vol. 108, no. 4154, p. 1-12.

FREITAS, CEC. and GARCEZ, RCS., 2004. Fish communities of natural canals between floodplain lakes and Solimões-Amazonas River. Acta Limnologica Brasiliensia, vol. 16, no. 3, p. 273-280.

FURCH, K. and JUNK, WJ., 1997. Physicochemical conditions in the floodplains. In JUNK, WJ. (Ed.). The Central Amazon floodplain: Ecology of a Pulsing System. New York: Springer Verlag, Ecological Studies. p. 69-108. vol. 126.. http://dx.doi. org/10.1007/978-3-662-03416-3_4.

GIARRIZZO, T. and KRUMME, U., 2009. Temporal patterns in the occurrence of selected tropical fishes in mangrove creeks: implications for the fisheries management in North Brazil. Brazilian Archives of Biology and Technology, vol. 52, no. 3, p. 679-688. http://dx.doi.org/10.1590/S1516-89132009000300020.

GILMAN, E., ELLISON, J. and COLEMAN, R., 2007. Assessment of mangrove response to projected relative sea-level rise and recent historical reconstruction of shoreline position. Environmental Monitoring and Assessment, vol. 124, no. 1-3, p. 105-130. http:// dx.doi.org/10.1007/s10661-006-9212-y. PMid:17171293 
GILMAN, EL., ELLISON, J., DUKE, NC. and FIELD, C., 2008. Threats to mangroves from climate change and adaptation options: A review. Aquatic Botany, vol. 89, no. 2, p. 237-250. http://dx.doi. org/10.1016/j.aquabot.2007.12.009.

GOPAL, B. and JUNK, WJ., 2000. Biodiversity in wetlands: an introduction. In: GOPAL, B., JUNK, WJ. and DAVIS, JA. (Eds.). Biodiversity in wetlands: assessment, function and conservation. Leiden: Backhuys Publishers. p. 1-10. vol. 1.

GOULDING, M., 1999. Introduction. In PADOCH, C., AYRES, JM., PINEDOVAZQUEZ, M. and HENDERSON, A. (Eds.). Várzea: diversity, development, and the conservation of Amazonian's whitewaters floodplain. Nova York: New York Botanical Garden Press. p. 3-6.

IPCC, 2007a. Contribution of Working Groups I, II and III to the Fourth Assessment Report of the Intergovernmental Panel on Climate Change. In CORE WRITING TEAM, PACHAURI, RK. and REISINGER, A. (Eds.). Climate Change 2007: Synthesis Report. Geneva: IPCC. p. 26-73.

IPCC, 2007b. Contribution of Working Group II to the Fourth Assessment Report of the Intergovernmental Panel on Climate Change. In PARRY, ML., CANZIANI, OF., PALUTIKOF, JP., VAN DER LINDEN, PJ. and HANSON, CE. (Eds). Climate Change 2007: Impacts, Adaptation and Vulnerability. Summary for Policymakers. Cambridge: Cambridge University Press. p. 7-22.

JUNK, WJ., 1993. Wetlands of tropical South America. In WHIGHAM, DF., DYKYJOVÁ, D. and HEJNÝ, S. (Eds.). Wetlands of the World I: Inventory, Ecology and Management. Dordrecht: KluwerAcademic Publishers. p. 679-739.

JUNK, WJ., 1997. The central Amazon floodplain: ecology of a pulsing system. Berlin: Springer Verlag. 525 p. Ecological Studies. http://dx.doi.org/10.1007/978-3-662-03416-3.

JUNK, WJ. and PIEDADE, MTF., 2004. Status of knowledge, ongoing research, and research needs in Amazonian wetlands. Wetlands Ecology and Management, vol. 12, no. 6, p. 597-609. http://dx.doi.org/10.1007/s11273-005-1767-9.

JUNK, WJ., BAYLEY, PB. and SPARKS, RE., 1989. The flood pulse concept in riverfloodplain systems. Canadian Special Publication of Fisheries and Aquatic Sciences, vol. 106, p. 110-127.

JUNK, WJ., SOARES, MGM. and BAYLEY, PB., 2007. Freshwater fishes of the Amazon River basin: their biodiversity, fisheries, and habitats. Aquatic Ecosystem Health \& Management, vol. 10, no. 2, p. 153-173. http://dx.doi.org/10.1080/14634980701351023.

JUNK, WJ., PIEDADE, MTF., SCHÖNGART, J., COHN-HAFT, M., ADENEY, JM. and WITTMANN, F., 2011. A classification of major naturally-occurring Amazonian lowland wetlands. Wetlands, vol. 31, no. 4, p. 623-640. http://dx.doi.org/10.1007/ s13157-011-0190-7.

KEDDY, PA., FRASER, LH., SOLOMESHCH, AI., JUNK, WJ., CAMPBELL, DR., ARROYO, MTK. and ALHO, CJR., 2009. Wet and wonderful: the world's largest wetlands are conservation priorities. BioSciencie, vol. 59, no. 1, p. 39-51. http://dx.doi. org/10.1525/bio.2009.59.1.8

KJERFVE, B. and LACERDA, LD., 1993. Mangroves of Brazil. In LACERDA, LD. (Ed.). Conservation and Sustainable Utilization of Mangrove Forests in Latin America and Africa Regions. Okinawa: ITTO/International Society for Mangrove Ecosystems. p. 245-272.

KJERFVE, B. and MACINTOSH, DJ., 1997. The impact of climatic change on mangrove ecosystems. In KJERFVE, B., LACERDA,
LD. and DIOP, ES. (Eds.). Mangrove Ecosystem Studies in Latin America and Africa. Paris: UNESCO/International Society for Mangrove Ecosystems. p. 1-7

KJERFVE, B., LACERDA, LD., REZENDE, CE. and OVALLE, ARC., 2000. Hydrological and hydrogeochemical variations in mangrove ecosystems. In YAÑEZ-ARACIBIA, A. and LARADOMINGUEZ, AL. (Eds.). Mangrove Ecosystems in Tropical America. Mexico: INNECOL. p. 71-81.

KJERFVE, B., PERILLO, GME., GARDNER, LR., RINE, JM., DIAS, GTM. and MOCHEL, FR., 2002. Morphodynamics of muddy environments along the Atlantic coasts of North and South America. In HEALY, TR., WANG, Y. and HEALY, JA. (Eds.). Muddy Coasts of the World: Processes, Deposits and Functions. Amsterdam: Elsevier Science. p. 479-532.. http:// dx.doi.org/10.1016/S1568-2692(02)80094-8.

LACERDA, LD. and KJERFVE, B., 1999. Conservation and management of Latin American mangroves. In SALOMONS, W., TURNER, RK., LACERDA, LD. and RAMACHANDRAN, S. (Eds.). Perspectives on Integrated Coastal Zone Management. Berlin: Spring Verlag. p. 183-194.. http://dx.doi.org/10.1007/9783-642-60103-3_10.

LACERDA, LD., GODOY, MD. and MAIA, LP., 2010. Mudanças climáticas globais: caçando indicadores no nordeste brasileiro. Ciência Hoje, vol. 46, no. 272, p. 32-37.

LACERDA, LD., CONDE, JE., KJERFVE, B., ALVAREZ LEON, R., ALARCÓN, C. and POLANÍA, J., 2002. American Mangroves. In LACERDA, LD. (Ed.). Mangrove ecosystems: function and management. Heidelberg: Springer Verlag. p. 1-62.. http://dx.doi.org/10.1007/978-3-662-04713-2_1.

LACERDA, LD., CONDE, JE., BACON, PR., ALARCON, C., D'CROZ, L., KJERFVE, B., POLANIA, J. and VANNUCCI, M., 1993. Mangrove ecosystems of Latin America and the Caribbean: a summary. In LACERDA, LD. (Ed.). Conservation and Sustainable Utilization of Mangrove Forests in Latin America and Africa Regions. Okinawa: ITTO/International Society for Mangrove Ecosystems. p. 1-42. Part I - Latin America.

LAKE, PS., PALMER, MA., BIRO, P., COLE, J., COVICH, AP., DAHM, C., GIBERT, J., GOEDKOOP, W., MARTENS, K. and VERHOEVEN, J., 2000. Global change and the biodiversity of freshwater ecosystems: impacts on linkages between aboveSediment and sediment biota. Bioscience, vol. 50, no. 12, p. 10991107. http://dx.doi.org/10.1641/0006-3568(2000)050[1099:GC АТВO]2.0.CO;2.

LOWE-MCCONNELL, RH., 1999. Estudos ecológicos de comunidades de peixes tropicais. São Paulo: Editora da Universidade de São Paulo. 534 p.

MALHI, Y., ARAGÃO, LEOC., GALBRAITH, D., HUNTINGFORD, C., FISHER, R., ZELAZOWSKI, P., SITCH, S., MCSWEENEY, C. and MEIR, P., 2009. Exploring the likelihood and mechanism of a climate-change-induced dieback of the Amazon rainforest. Proceedings of the National Academy of Sciences of the United States of America, vol. 106, no. 49, p. 20610-20615. http://dx.doi. org/10.1073/pnas.0804619106. PMid:19218454

MARENGO, JA., 2007. Mudanças climáticas globais e seus efeitos sobre a biodiversidade: caracterização do clima atual e definição das alterações climáticas para o território brasileiro ao longo do século XXI. 2nd ed. Brasília: Ministério do Meio Ambiente. 212 p.

MARENGO, JA. and NOBRE, CA., 2001. The hydroclimatological framework in Amazonia. In RICHEY, J., MCCLAINE, M. and 
VICTORIA, R. (Eds.). Biogeochemistry of Amazonia. Oxford: Oxford University Press. p. 17-42.

MARENGO, JA. and SOARES, WR., 2003. Impacto das modificações da mudança climática: Síntese do Terceiro Relatório do IPCC. Condições climáticas e recursos hídricos no Norte do Brasil. In FBMC; ABRH. (Orgs.). Clima e Recursos Hídricos no Brasil. Porto Alegre: Associação Brasileira de Recursos Hídricos. p. 209-233.

MARENGO, JA., TOMASELLA, J. and NOBRE, CA., 2010. Mudanças climáticas e recursos hídricos. In BICUDO, CEM., TUNDISI, JG. and SCHEUENSTUHL, MCB. (Org.). Águas do Brasil: Análises Estratégicas. São Paulo: Instituto de Botânica. p. 201-215.

MARENGO, JA., TOMASELLA, J., ALVES, LM. and SOARES, WR., 2011a. Eventos extremos sazonais: secas de 2005 e 2010 e enchentes de 2009. In MARENGO, JA. and BETTS, R. (Coords.). Riscos das mudanças climáticas no Brasil: análise conjunta Brasil-Reino Unido sobre os impactos das mudanças climáticas e do desmatamento na Amazônia. São José dos Campos: INPE/ MOHC. p. 21-24.

MARENGO, JA., TOMASELLA, J., SOARES, WR., ALVES, LM. and NOBRE, CA., 2012. Extreme climatic events in the Amazon basin. Theoretical and Applied Climatology, vol. 107, no. 1-2, p. 73-85. http://dx.doi.org/10.1007/s00704-011-0465-1.

MARENGO, JA., AMBRIZZI, T., ROCHA, RP., ALVES, LM., CUADRA, SV., VALVERDE, MC., TORRES, RR., SANTOS, DC. and FERRAZ, SET., 2009a. Future change of climate in South America in the late twenty-first century: intercomparison of scenarios from three regional climate models. Climate Dynamics, vol. 35 , p. 1089-1113.

MARENGO, JA., TOMASELLA, J., ALVES, LM., SOARES, WR. and RODRIGUEZ, DA., 2011b. The drought of 2010 in the context of historical droughts in the Amazon region. Geophysical Research Letters, vol. 38, no. L12703, p. 1-5.

MARENGO, JA., JONES, R., ALVES, LM. and VALVERDE, CM., 2009b. Future change of temperature and precipitation extremes in South America as derived from the PRECIS regional climate modeling system. International Journal of Climatology, vol. 30, p. 1-15.

MENEZES, MPM. and MEHLIG, U., 2009. Manguezais: As florestas da Amazônia costeira. Ciência Hoje, vol. 44, no. 264, p. 34-39.

MEYER, JL., SALE, MJ., MULhOLLAND, PJ. and POFF, NL., 1999. Impacts of climate change on aquatic ecosystem functioning and health. Journal of the American Water Resources Association, vol. 35, no. 6, p. 1373-1386. http://dx.doi. org/10.1111/j.1752-1688.1999.tb04222.x.

Millennium Ecosystem Assessment, 2005. Ecosystems and human well-being: wetlands and water synthesis. Washington: World Resources Institute. 68 p.

MITSCH, WJ. and GOSSELINK, JG., 2007. Wetlands. 4th ed. New Jersey: John Wiley and Sons, Inc. 582 p.

MITSCH, WJ., NAHLIK, A., WOLSKI, P., BERNAL, B., ZHANG, LI. and RAMBERG, L., 2010. Tropical wetlands: Seasonal hydrologic pulsing, carbon sequestration, and methane emissions. Wetlands Ecology and Management, vol. 18, no. 5, p. 573-586. http://dx.doi.org/10.1007/s11273-009-9164-4.
MUEHE, D. and NEVES, C.F., 1995. The implication of sea level rise on the Brazilian coast: a preliminary assessment. Journal of Coastal Research, no. 14, p. 54-78.

MULHOLLAND, PJ., BEST, GR., COUTANT, CC., HORNBERGER, GM., MEYER, JL., ROBINSON, PJ., STENBERG, JR., TURNER, RE., VERA-HERRERA, F. and WETZEL, RG., 1997. Effects of climate change on freshwater ecosystems of the south-eastern United States and the gulf coast of México. Hydrological Processes, vol. 11, no. 8, p. 949-970. http://dx.doi.org/10.1002/(SICI)10991085(19970630)11:8<949::AID-HYP513>3.0.CO;2-G.

MUMBY, PJ., EDWARDS, AJ., ARIAS-GONZÁLEZ, JE., LINDEMAN, KC., BLACKWELL, PG., GALL, A., GORCZYNSKA, MI., HARBORNE, AR., PESCOD, CL., RENKEN, H., WABNITZ, CC. and LLEWELLYN, G., 2004. Mangroves enhance the biomass of coral reef fish communities in the Caribbean. Nature, vol. 427, no. 6974 , p. 533-536. PMid:14765193

NEVES, CF. and MUEHE, D., 2008. Vulnerabilidade, impactos e adaptação a mudanças do clima: a zona costeira. Parcerias Estratégicas, vol. 27, p. 217-295.

NICHOLLS, RJ., WONG, PP., BURKETT, VR., CODIGNOTTO, JO., HAY, JE., MCLEAN, RF., RAGOONADEN, S. and WOODROFFE, CD., 2007. Coastal systems and low-lying areas. In PARRY, ML., CANZIANI, OF., PALUTIKOF, JP., VAN DER LINDEN, PJ. and HANSON, CE. (Eds.). Climate Change 2007: Impacts, Adaptation and Vulnerability. Contribution of Working Group II to the Fourth Assessment Report of the Intergovernmental Panel on Climate Change. Cambridge: Cambridge University Press. p. 315-356.

NIELSEN, DL. and BROCK, MA., 2009. Modified water regime and salinity as a consequence of climate change: prospects for wetlands of Southern Australia. Climatic Change, vol. 95, no. 3-4, p. 523-533. http://dx.doi.org/10.1007/s10584-009-9564-8.

PAROLIN, P., LUCAS, C., PIEDADE, MT. and WITTMANN, F., 2010. Drought responses of flood-tolerant trees in Amazonian floodplains. Annals of Botany, vol. 105, no. 1, p. 129-139. http:// dx.doi.org/10.1093/aob/mcp258. PMid:19880423

PAROLIN, P., DE SIMONE, O., HAASE, K., WALDHOFF, D., ROTTENBERGER, S., KUHN, U., KESSELMEIER, J., KLEISS, B., SCHMIDT, W., PIEDADE, MTF. and JUNK, WJ., 2004. Central Amazon floodplain forests: tree survival in a pulsing system. Botanical Review, vol. 70, no. 3, p. 357-380. http://dx.doi. org/10.1663/0006-8101(2004)070[0357:CAFFTA]2.0.CO;2.

PEREIRA, LCC., DIAS, JA., CARMO, JA. and POLETTE, M., 2009. A Zona Costeira Amazônica Brasileira. Revista de Gestão Costeira Integrada, vol. 9, no. 2, p. 3-7. http://dx.doi. org/10.5894/rgci172.

PIRES, GA., 2011. Áreas Úmidas e Patrimônio Natural: uma visão estratégica para a água em espaços transfronteiriços? Novos Cadernos NAEA, vol. 14, no. 1, p. 97-114.

PITCHFORD, JL., WU, C., LIN, LS., PETTY, JT., THOMAS, R., VESELKA, IVWE., WELSCH, D., ZEGRE, N. and ANDERSON, JT., 2012. Climate change effects on hydrology and ecology of wetlands in the mid-Atlantic highlands. Wetlands, vol. 32, no. 1, p. 21-33. http://dx.doi.org/10.1007/s13157-011-0259-3.

POFF, NL., 2002. Ecological response to and management of increased flooding caused by climate change. The Royal Society of London. Series A, vol. 360, no. 1796, p. 1497-1510. http:// dx.doi.org/10.1098/rsta.2002.1012. 
POFF, NL. and ZIMMERMAN, JKH., 2010. Ecological responses to altered flow regimes: a literature review to inform the science and management of environmental flows. Freshwater Biology, vol. 55, no. 1, p. 194-205. http://dx.doi.org/10.1111/j.13652427.2009.02272.x

POFF, NL., BRINSON, M. and DAY, JB., 2002. Freshwater and coastal ecosystems and global climate change: a review of projected impacts for the United States. Virginia: Pew Center on Global Climate Change. 44 p.

PRANCE, TG., 1980. A terminologia dos tipos de florestas amazônicas sujeitas a inundação. Acta Amazonica, vol. 10, no. 3, p. 495-504.

PUJOLAR, JM., VINCENZI, S., ZANE, L., JESENSEK, D., DE LEO, GA. and CRIVELLI, AJ., 2011. The effect of recurrent floods on genetic composition of marble trout populations. PLoS ONE, vol. 6, no. 9, p. e23822. http://dx.doi.org/10.1371/journal. pone.0023822. PMid:21931617

QUEIROZ, HL., 2005. A reserva de desenvolvimento sustentável Mamirauá. Estudos Avançados, vol. 19, no. 54, p. 183-203. http:// dx.doi.org/10.1590/S0103-40142005000200011.

RAMÍREZ, E., 2008. Impactos del cambio climático y gestión del agua sobre la disponibilidad de recursos hídricos para las ciudades de La Paz y El Alto. Revista Virtual REDESMA, vol. 2 , no. 3 , p. 50-61.

RAMÍREZ, E., FRANCOU, B., RIBSTEIN, P., DESCLOITRES, M., GUÉRIN, R., MENDOZA, J., GALLAIRE, R., POUYAUD, B. and JORDAN, E., 2001. Small glaciers disappearing in the tropical Andes: A case study in Bolivia: Glaciar Chacaltaya $\left(16^{\circ} \mathrm{S}\right)$. Journal of Glaciology, vol. 47, no. 157, p. 187-194. http://dx.doi. org/10.3189/172756501781832214.

RAMSAR, 1971. Convention on Wetlands of International Importance especially as Waterfowl Habitat, 1971. Ramsar. Ramsar: UN Treaty Series No. 14583.
RUFFINO, ML., 2004. A pesca e os recursos pesqueiros na Amazônia brasileira. Manaus: IBAMA. 262 p.

SOUSA, RGC. and FREITAS, CEC., 2008. The influence of flood pulse on fish communities of floodplain canals in the middle Solimões River, Brazil. Neotropical Ichthyology, vol. 6, no. 2, p. 249-255. http://dx.doi.org/10.1590/S1679-62252008000200013.

SOUZA FILHO, PWM. and EL-ROBRINI, M., 1997. Morfologia, Processos de sedimentação e litofácies dos ambientes morfosedimentares da PLanície Costeira Bragantina, NE do Pará (Brasil). Geonomes, vol. 4, no. 2, p. 1-16.

TOMASELLA, J., BORMA, SL., MARENGO, JA., RODRIGUEZ, DA., CUARTAS, LA., NOBRE, CA. and PRADO, MCR., 2010. The droughts of 1996-1997 and 2004-2005 in Amazonia: hydrological response in the river main-stem. Hydrological Processes, vol. 10.

TUNDISI, JG. and MATSUMURA-TUNDISI, T., 2008. Limnologia. São Paulo: Oficina de Textos. 632 p.

VIEIRA, AR., 2006. Educação ambiental pelas águas do Brasil. In COSTA, L. and BARRÊTO, SR. (Coords.). Cadernos de Educação Ambiental, Água para Vida, Água para Todos: Livro das Águas. Brasília: WWF-Brasil, p. 4-5.

WRONA, FJ., PROWSE, TD., REIST, JD., HOBBIE, JE., LÉVESQUE, LMJ. and VINCENT, WF., 2006. Climate change effects on aquatic biota, ecosystem structure and function. Ambio, vol. 35, no. 7, p. 359-369. http://dx.doi.org/10.1579/00447447(2006)35[359:CCEOAB]2.0.CO;2. PMid:17256640

ZUANON, J., 2008. Peixes, pesca e clima na Amazônia: um ensaio sobre os efeitos das mudanças climáticas globais sobre os recursos pesqueiros na região do Rio Negro, Amazonas, Brasil. In CRUZ, GVP. and ANDRADE, S. (Orgs.). Rio Negro, Manaus e as Mudanças no Clima. 1st ed. Manaus: Editora do ISA. p. 31-39. vol. 1. 